

\section{DISCLAIMER}

This report was prepared as an account of work sponsored by an agency of the United States Government. Neither the United States Government nor any agency Thereof, nor any of their employees, makes any warranty, express or implied, or assumes any legal liability or responsibility for the accuracy, completeness, or usefulness of any information, apparatus, product, or process disclosed, or represents that its use would not infringe privately owned rights. Reference herein to any specific commercial product, process, or service by trade name, trademark, manufacturer, or otherwise does not necessarily constitute or imply its endorsement, recommendation, or favoring by the United States Government or any agency thereof. The views and opinions of authors expressed herein do not necessarily state or reflect those of the United States Government or any agency thereof. 


\section{DISCLAIMER}

Portions of this document may be illegible in electronic image products. Images are produced from the best available original document. 


\section{NOTICE}

This report was prepared as an account of work sponsored by the United States Government. Neither the United States nor the United States Energy Research and Development Administration, nor any of their employees, nor any of their contractors, subcontractors, or their employees, makes any warranty, express or implied, or assumes any legal liability or responsibility for the accuracy, com-

pleteness or usefulness of any information, apparatus, product or process disclosed or represents that its use would not infringe privately owned rights. 
MLM-2435

UC.70

\title{
Decontamination of HEPA Filters: January-March 1977
}

\author{
Don F. Luthy and Edward L. Lewis
}

Issued: July 22, 1977

PRINTED IN THE UNITED STATES OF AMERICA

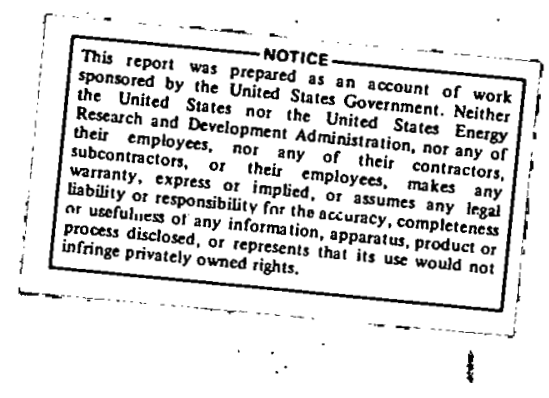

Avalloble from

Notional Technical informetion Sorvice

U. S. Deportment of Commerce

5285 Port Royal Rosd

Springtield, Virginia 22161

Price: Printed Copy \$3.50; Miciotiche \$3.00

\section{MONSANTO RESEARCH CORPORATION}

A Subsidiary of Monsanto Company

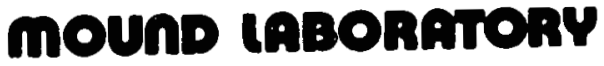 \\ Miamisburg, Ohio $\quad 45342$ \\ operated for
}

\section{UNITED STATES ENERGY RESEARCH AND DEVELOPMENT ADMINISTRATION}

U. S: Government Contract No. EY.76-C-04-0053 


\section{Table of Contents}

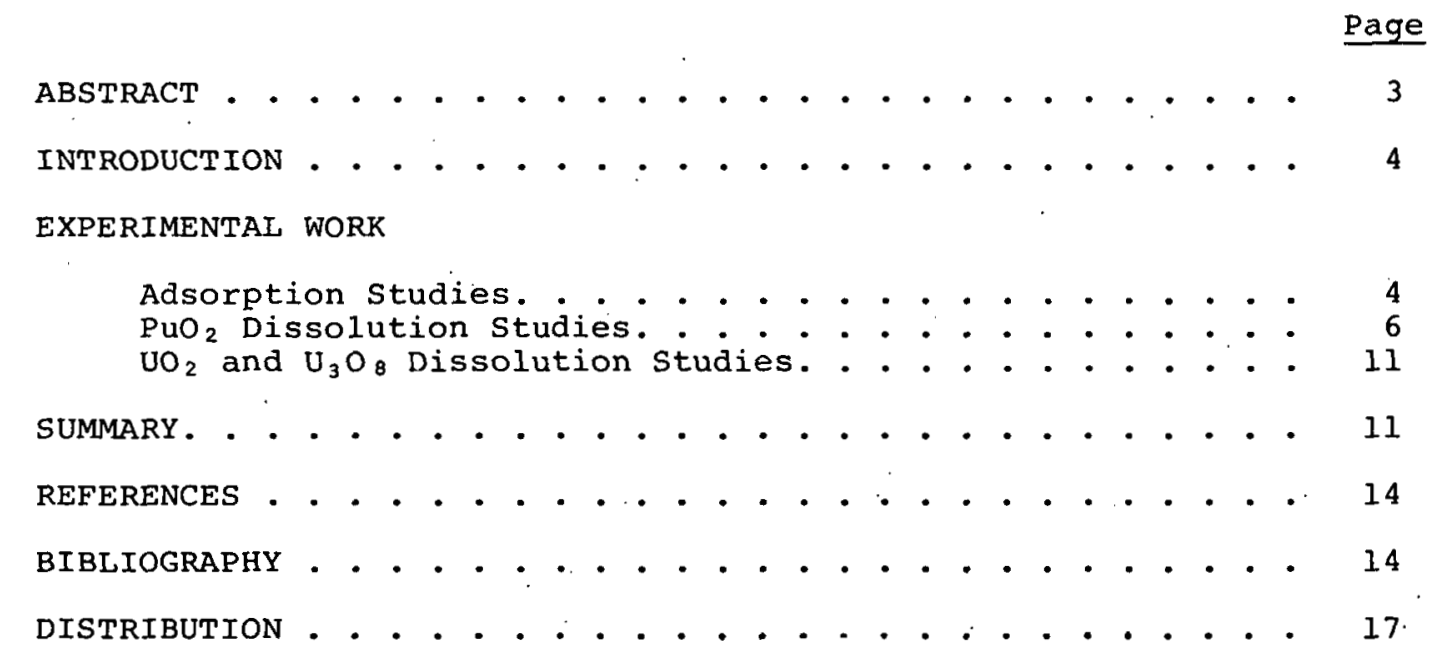




\section{Abstract}

Various leaching agents were tested to determine their capability for dissolving $\mathrm{PuO}_{2}, \mathrm{UO}_{2}$, and $\mathrm{U}_{3} \mathrm{O}_{8}$. The amount of radionuclides retained by the filter media was investigated. Adsorption isotherms for two leaching systems were obtained. A four-stage dissolution process was developed. 


\section{Introduction}

Efforts this past quarter were directed toward determining the dissolution parameters of $\mathrm{PuO}_{2}, \mathrm{UO}_{2}$, and $\mathrm{U}_{3} \mathrm{O}_{8}$ * in various leach reagents. The reagents used were various concentrations of $\mathrm{HNO}_{3}, \mathrm{HNO}_{3}-\mathrm{HF}$, $\mathrm{HNO}_{3}-\mathrm{HF}-\mathrm{H}_{2} \mathrm{SO}_{4}, \mathrm{HNO}_{3}-$ $\left(\mathrm{NH}_{4}\right)_{2} \mathrm{Ce}\left(\mathrm{NO}_{3}\right)_{6}$, and $\mathrm{HNO}_{3}-\mathrm{H}_{2} \mathrm{SO}_{4}$. TwO types of plutonium dissolution tests were conducted with $8 \mathrm{~N} \mathrm{HNO}_{3}$. In the one; $\mathrm{PuO}_{2}$ was placed in $8 \underline{\mathrm{N}} \mathrm{HNO}_{3}$ at boiling temperature. In the other, HEPA filter media contaminated with $\mathrm{PuO}_{2}$ were added to boiling $8 \mathrm{~N} \mathrm{HNO}_{3}$. The dissnlution ratoc of $\mathrm{PuO}_{2}$ as measured by the alpha activity of the acid media were determined for each test and are shown in Figure 1. As can be seen, the apparent dissolution rate was less in the test using $\mathrm{PuO}_{2}-$ contaminated filter media. After $14 \mathrm{hr}$ of heating, for example, there was a $3 \%$ difference (118 minus 88$)$ in dissolution rates. At this point, plutonium adsorption isotherms were developed to determine whether any of the dissolved plutonlum was being adsorbed by the filter media. This is of great importance since the amount of adsorbed plutonium would be the limiting factor as to what decontamination factor could be achieved. Adsorption isotherms were determined for the $\mathrm{Pu}-\mathrm{HNO}_{3}$ and $\mathrm{Pu}-\mathrm{HNO}_{3}-\mathrm{HF}$ systems.

*The uranium oxides were depleted uranium-238, whereas the plutonium dioxide was a mixture of 80 wt $\%$ plutonium-238, 16 wt $\%$ plutonium-239, 2.5 wt 8 plutonium-240, 0.8 wt $\&$ plutonium-24l, 0.2 wt 8 plutonium-242, plus small amounts of other actinides calcined at $750^{\circ} \mathrm{C}$.

\section{Experimental Work}

\section{Adsorption Studies}

Standard plutonium solutions were prepared by dissolving $\mathrm{PuO}_{2}$ in boiling $8 \underline{\mathrm{N}}$ $\mathrm{HNO}_{3}$ - The HEPA filter media were shredded and ball-milled to $<40$ mesh. The filter media were placed in $100 \mathrm{ml}$ of the prepared $\mathrm{PuO}_{2}$-acid solution and stirred magnetically for several hours to reach equilibrium. A blank sample was run without filter media to correct for adsorption on the test beakers. All tests were made at ambient temperature $\left(220^{\circ} \mathrm{C}\right)$.

Figure 2 shows the adsorption of plutonium on filter media in different acids. The ordinate is $\mathrm{x} / \mathrm{m}$, where $\mathrm{x}=$ milligrams of plutonium-238 adsorbed and $\mathrm{m}=\mathrm{milli}-$ grams of filter media. The abscissa is $C$ which is the concentration of the solution in equilibrium with the filter media (expressed in milligrams plutonium-238 per milliliter of solution). The Freundlich equation [1] relates $x / m$ and $C$ as follows :

$$
\mathrm{x} / \mathrm{m}=\mathrm{kc} \mathrm{c}^{1 / \mathrm{n}}
$$

or

$$
\log (x / m)=\log k+(1 / n) \log c
$$

The plot of $\log (\mathrm{x} / \mathrm{m})$ as a function of $\log \mathrm{C}$ should be a straight line with slope $1 / n$ and $\log k$ the point of intercept. The straight lines in Figure 2 are such a plot. It should be noted that for any given concentration, the $\mathrm{x} / \mathrm{m}$ ratio is smaller for the $8 \underline{\mathrm{N}} \mathrm{HNO}_{3}-0.1 \mathrm{~N} \mathrm{HF}$ system. This means that a larger decontamination factor could be achieved using the $\mathrm{HNO}_{3}-$ HF leaching agent (assuming that the same percentage of plutonium dioxide is 


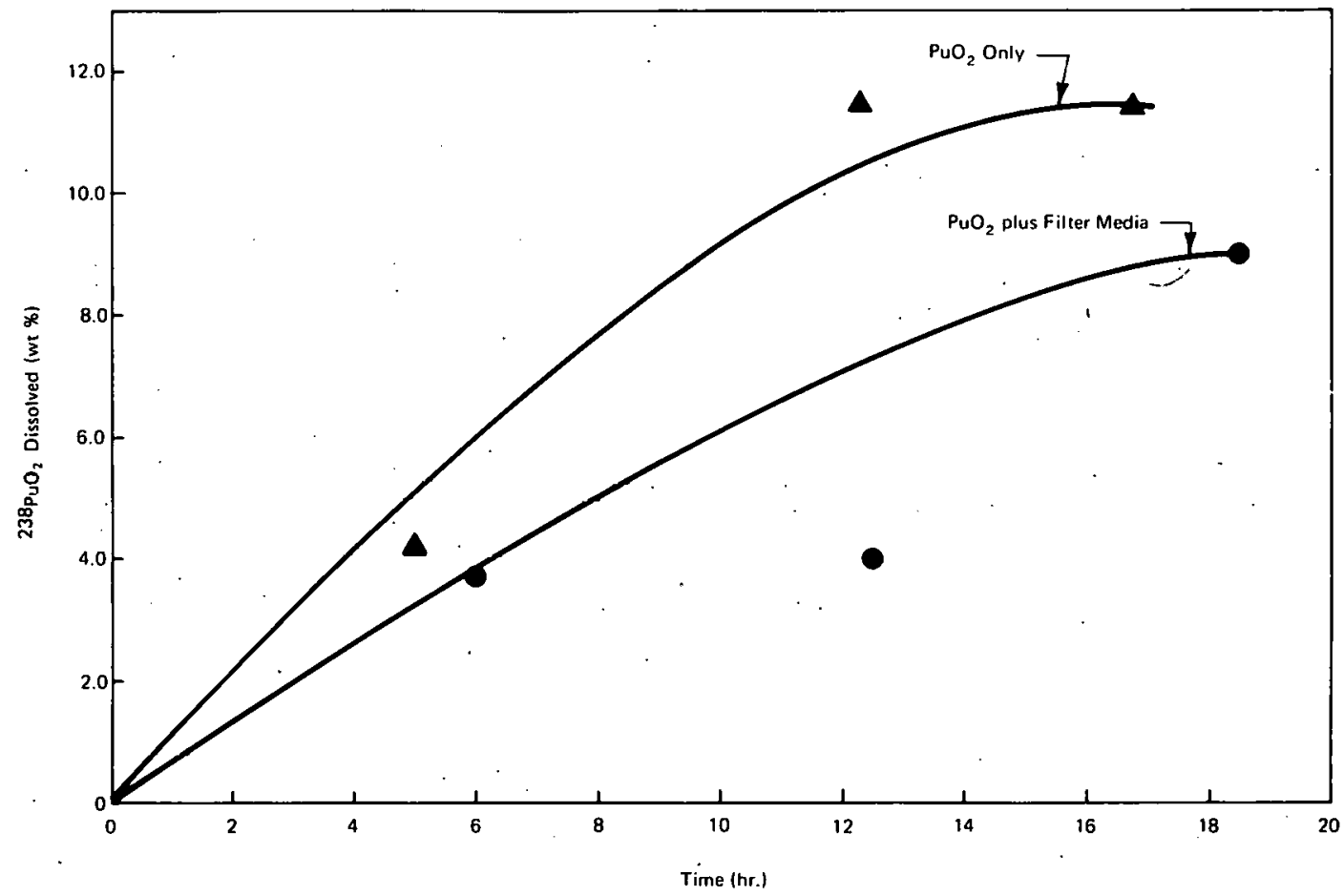

FIGURE 1 - Effect of filter media on dissolution rates of $\mathrm{PuO}_{2}$ in boiling $8 \mathrm{~N} \mathrm{HNO}_{3}$.

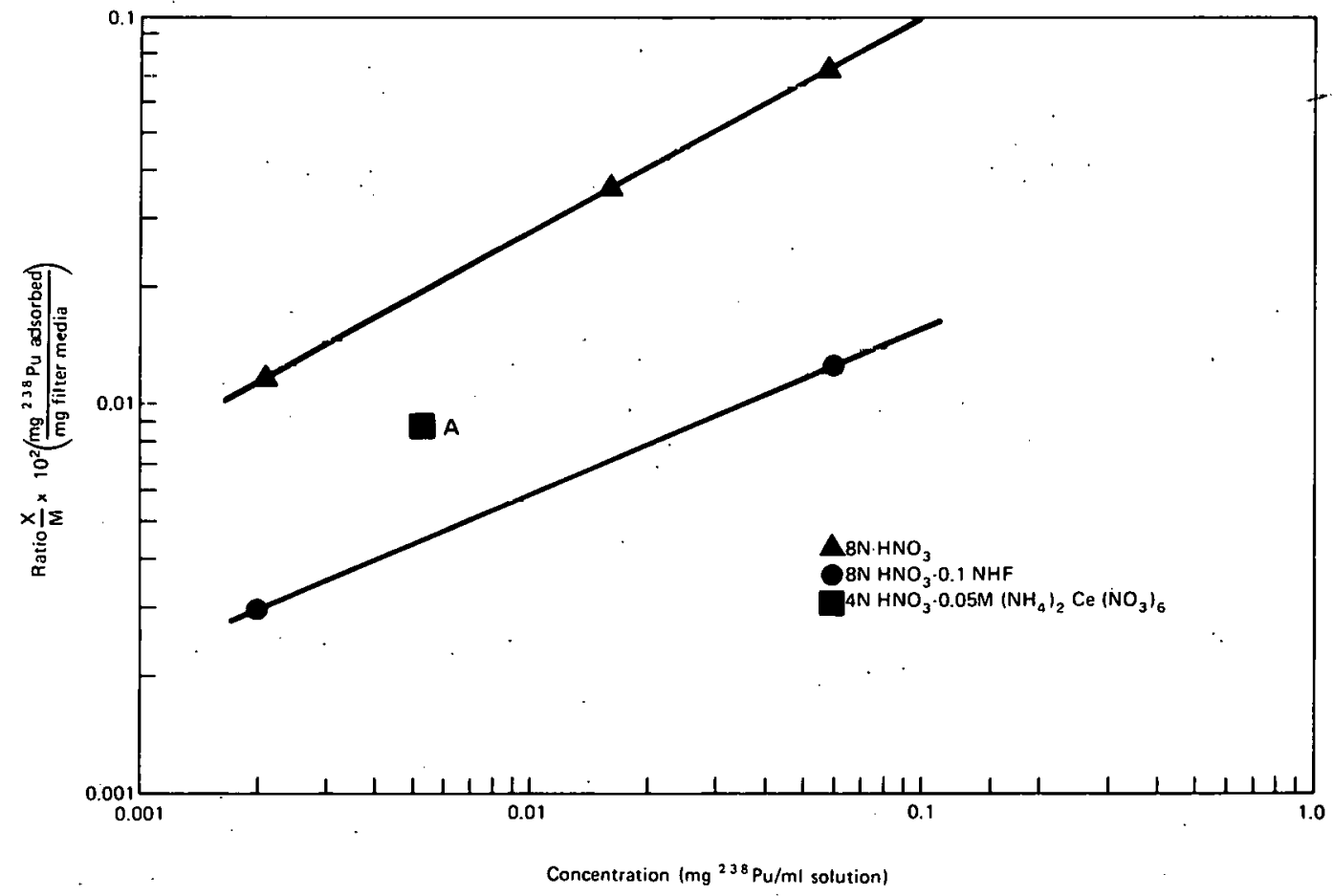

FIGURE 2 - Adsurplion of. $238 \mathrm{Pu}$ on filter media at ambient temperature $\left(\sim 20^{\circ} \mathrm{C}\right)$ in different acids. 
dissolved by either reagent in the dissolution step).

Tests were also performed to determine the solubility of the filter media in various dissolution reagents. It was determined that approximately 30 wt 8 of the filter media is soluble in $8 \underline{\mathrm{N}} \mathrm{HNO}_{3}$ and approximately 50 wt $z$ of the filter media dissolves in $8 \underline{\mathrm{N}} \mathrm{HNO}_{3}-0.1 \mathrm{~N} \mathrm{HF}$. Also, in another adsorption test it was found that the use of $4 \underline{\mathrm{N}} \mathrm{HNO}_{3}-0.05 \underline{\mathrm{M}}$ ceric ammonium nitrate (see point A, Figure 2) would achieve a decontamination factor somewhere between $8 \mathrm{~N} \mathrm{HNO}_{3}-0.1 \mathrm{~N} \mathrm{HF}$ and $8 \underline{\mathrm{N}}$ $\mathrm{HNO}_{3}$ (assuming each leaching agent was equally effective in dissolving plutonium dioxide).

\section{$\mathrm{PuO}_{2}$ Dissolution Studies}

Contaminated HEPA filter media were prepared by mixing plutonium dioxide powder with shredded filter media. The plutonium-238 concentration of the mixture was $1 \mathrm{mg} / \mathrm{ml}$ of prepared media. Small samples of this prepared mixture (about $3 \mathrm{~g}$ ) were added to glass beakers containing $250 \mathrm{ml}$ of leaching solution. All tests were performed at boiling temperatures. Samples were withdrawn periodically and the plutonium-238 concentration of the solution was determined. The contents of the beakers were stirred every $2 \mathrm{hr}$. The solution volume and concentration were kept constant by adding acid of proper concentration in order to replaoc cvaporated acid.

Table 1 lists results from dissolution tests for plutonium dioxide in various acid mixtures. The $\mathrm{HNO}_{3}-\mathrm{H}_{2} \mathrm{SO}_{4}$ mixtures were relatively ineffective dissolution agents as illustrated in Figure 3 . A fivefold increase in $\mathrm{H}_{2} \mathrm{SO}_{4}$ concentration increased the dissolution rate by only 38. The maximum weight percent plutonium238 dioxide dissolved was only 188 after an 18-hr reaction time. Figure 4 illustrates the effect of initial cerium(IV) concentration on the dissolution rate. The $4 \underline{\mathrm{N}} \mathrm{HNO}_{3}-0.1 \mathrm{M}\left(\mathrm{NH}_{4}\right)_{2} \mathrm{Ce}\left(\mathrm{NO}_{3}\right)_{6}$ leaching agent was by far the most effective of the three $\mathrm{HNO}_{3}$-cerium(IV) solutions with $88 \%$ of the plutonium-238 dioxide dissolved in $3 \mathrm{hr}$. Figure 5 is a companion graph showing the effect of initial cerium(IV) concentration on the dissolution rate for a 6-hr reaction time. Since the plot is approximately a straight line, the weight percent plutonium dioxide dissolved is directly proportional to the initial cerium(IV) concentration in the leaching solution.

The dissolution reaction mechanism for dissolving plutonium dioxide in $\mathrm{HNO}_{3}-\mathrm{cer}-$ ium(IV) solutions is shown in Equations 3 and 4 .

$$
\begin{aligned}
& 2 \mathrm{Ce}^{+4}+2 \mathrm{e}^{-} \rightleftharpoons 2 \mathrm{Ce}^{+3} \\
& \mathrm{Pu}^{+4} \rightleftharpoons \mathrm{Pu}^{+6}+2 \mathrm{e}^{-}
\end{aligned}
$$

Because stoichiometric quantities of cerium(IV) are required for complete dissolution of the plutonium dioxide, large amounts of cerium(IV) are required to dissolve large quantities of plutonium dioxide. Therefore, it would seem advantagenus to uac small dulunts of cerium(IV) and then add oxidizing compounds to re-oxidize the cerium(III) to cerium(IV). An example of this would be the addition of $\mathrm{KMnO}_{4}$ to the depleted solution. This would cause the $\mathrm{Mn}^{+7}+3 \mathrm{e}^{-} \rightleftharpoons \mathrm{Mn}^{+}{ }_{4}$ reaction which would reoxidize the depleted cerium, i.e., 


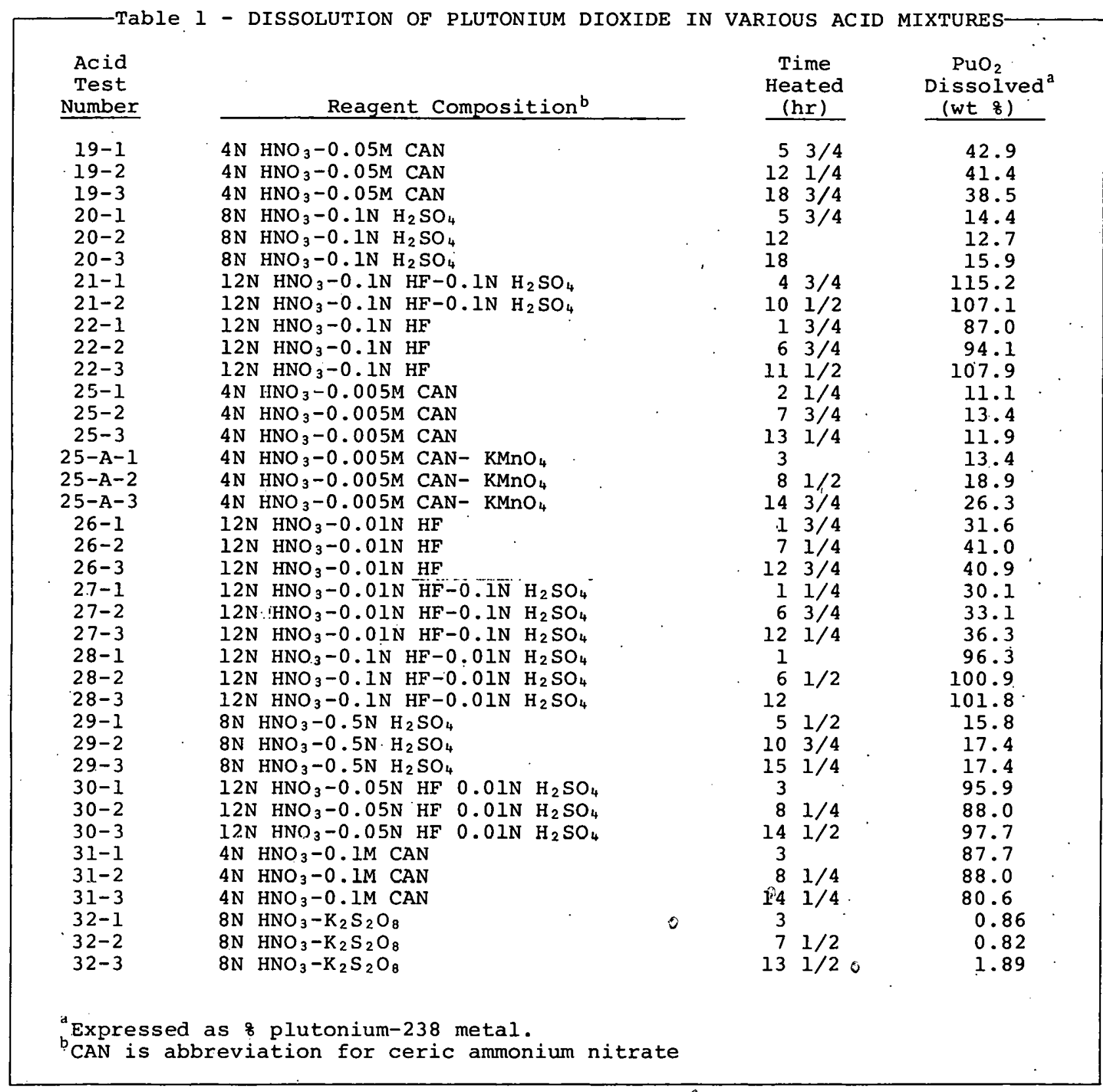

$$
\begin{aligned}
& 3 \mathrm{Ce}^{+3} \rightleftharpoons 3 \mathrm{Ce}^{+4}+3 \mathrm{e}^{-} \\
& \mathrm{Mn}^{+7}+3 \mathrm{e}^{-} \rightleftharpoons \mathrm{Mn}^{+4}
\end{aligned}
$$

where one mole of manganese oxidizes three moles of cerium. This was done in acid tests 25 and $25 \mathrm{~A}$ (see Table 1 ). Approximately $\mathrm{l} \mathrm{g}$ of $\mathrm{KMnO}_{4}$ was added to a depleted $4 \underline{\mathrm{N}} \mathrm{HNO}_{3}-0.005 \mathrm{M}\left(\mathrm{NH}_{4}\right)_{2} \mathrm{Ce}\left(\mathrm{NO}_{3}\right)_{6}$ solution and the solution heated an additional $15 \mathrm{hr}$. . In this period of time, the weight percent plutonium dioxide dissolved increased significantly from 128 in the depleted solution to $26 \%$ in the regenerated solution. This method does, however, add manganese and potassium to the dissolved salts of the waste stream.

Another experiment was conducted using $8 \mathrm{~N}^{-} \mathrm{HNO}_{3}$ and $\mathrm{K}_{2} \mathrm{~S}_{2} \mathrm{O}_{8}$ (potassium persulphate) as an oxidizing aqent (see Table 1, acid test 32 ). After $13 \frac{1}{2} \mathrm{hr}$ of reaction time 


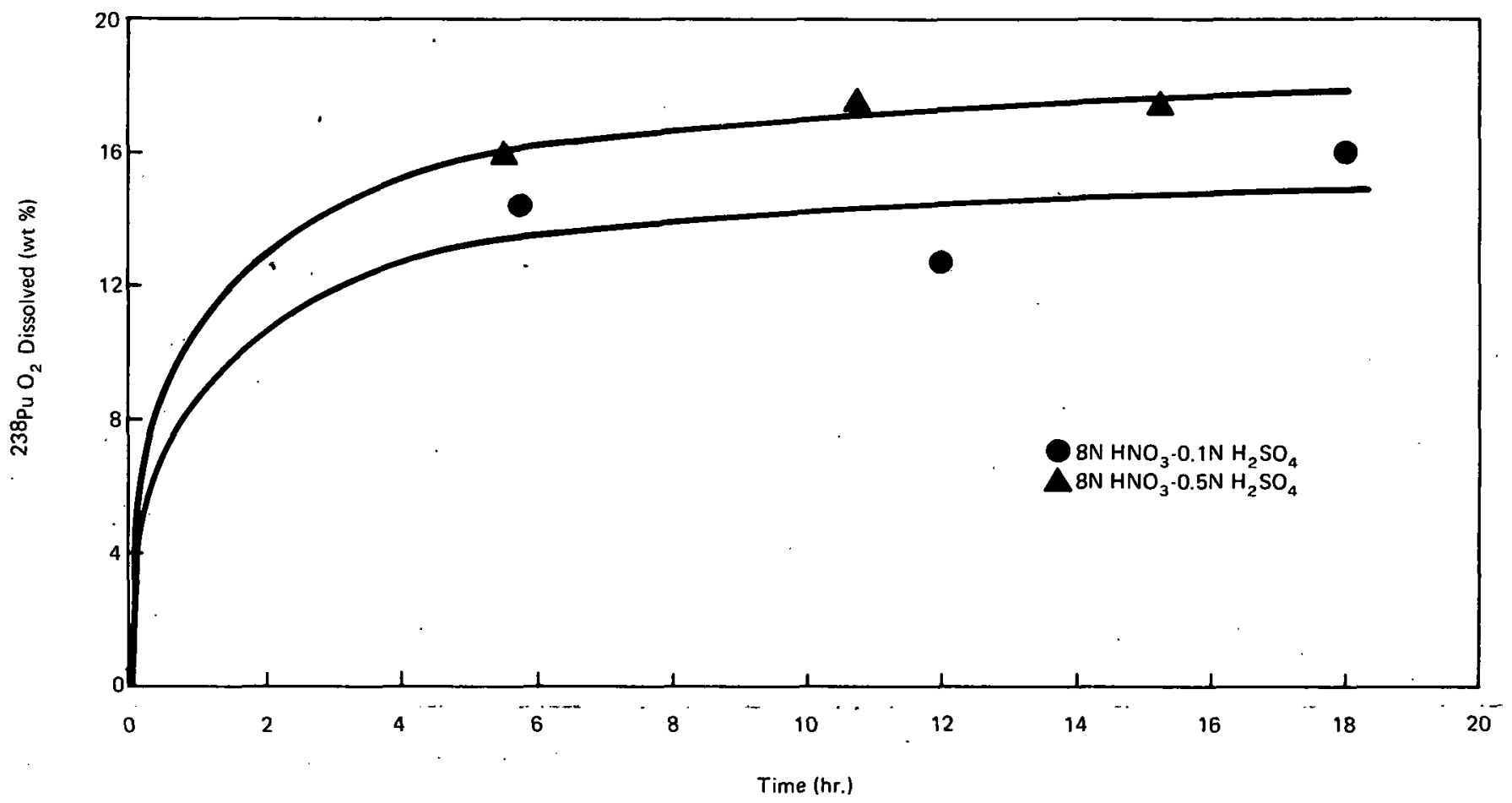

FIGURE 3 - Effect of $\mathrm{H}_{2} \mathrm{SO}_{4}$ concentration on dissolution rate.

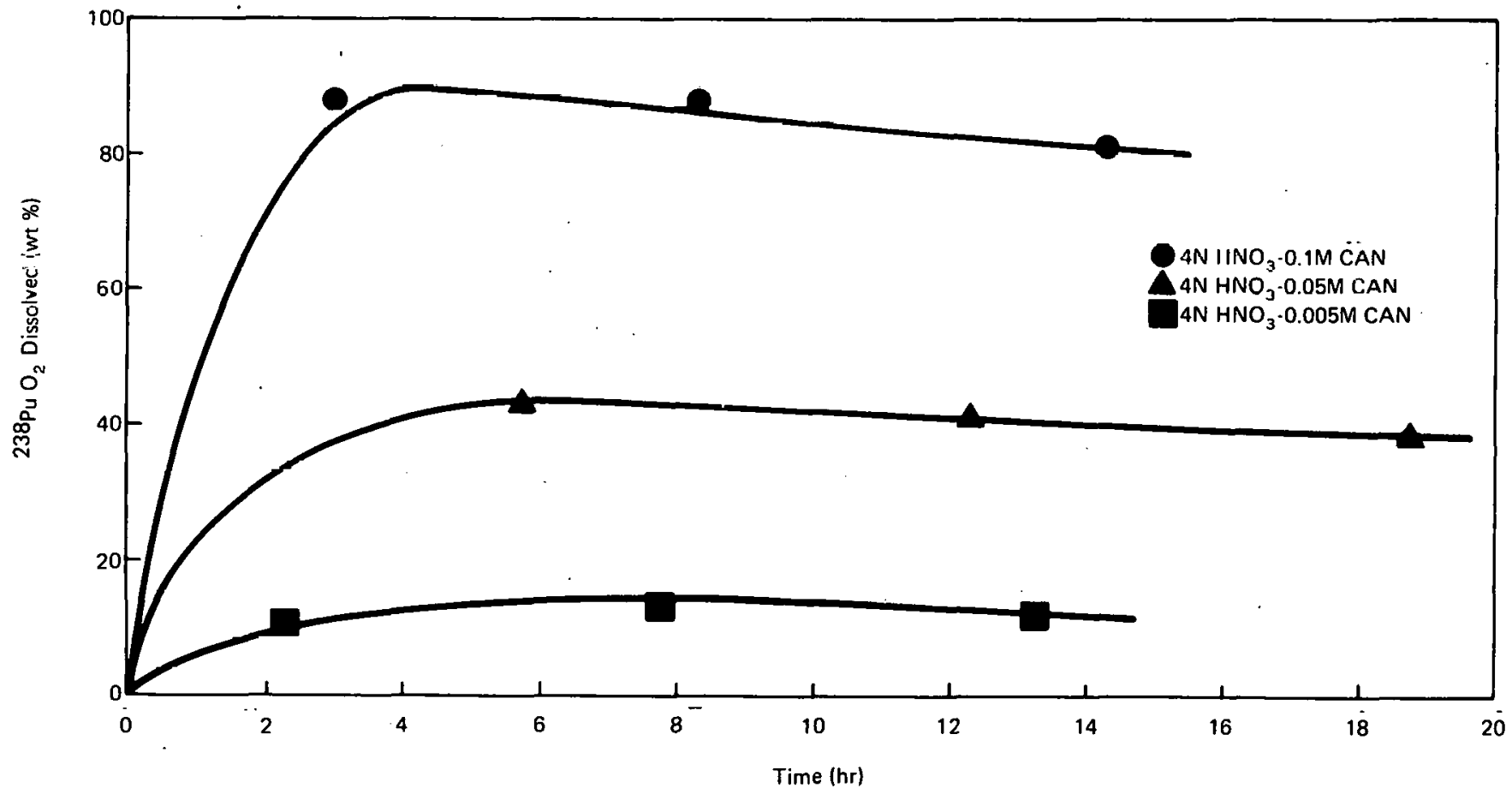

FIGURE 4 - Effect of ceric ammonium nitrate (CAN) concentration on dissolution rate. 


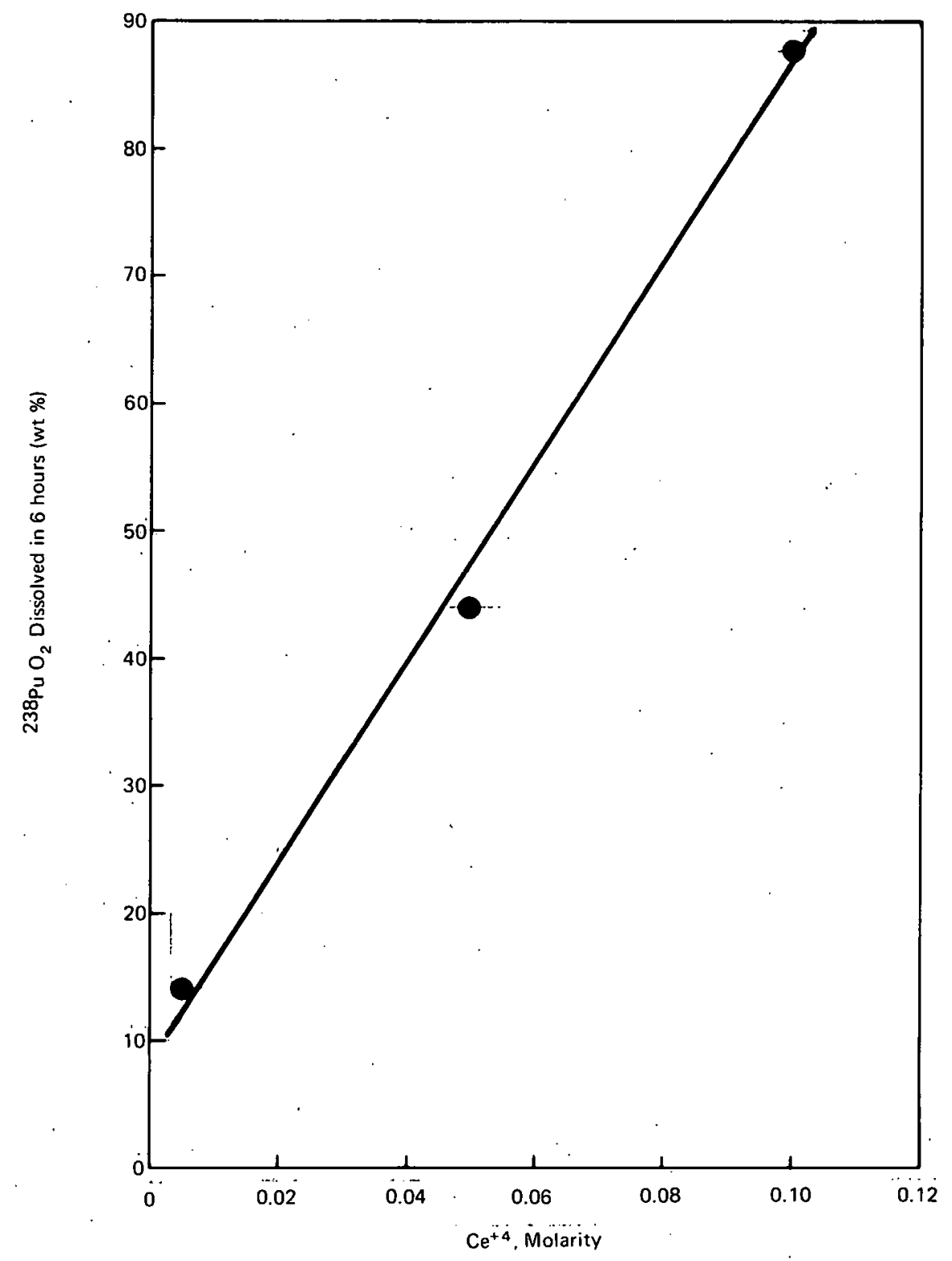

FIGURE 5 - Effect of $\mathrm{Ce}^{+4}$ on the dissolution of $\mathrm{PuO}_{2}$ in $4 \mathrm{NHNO}_{3}$.

at boiling temperature, only 1.898 of the plutonium dioxide had dissolved. From Figure 1, one can see that approximately 7.58 of the plutionium dioxide dissolved in $8 \mathrm{hr}$ with no additional oxidizing agent present. Thus the $\mathrm{K}_{2} \mathrm{~S}_{2} \mathrm{O}_{8}$ actually decreased the dissolution rate of the plutonium dioxide.

Figures 6 and 7 show the effect of the HF concentration on the dissolution rate of plutonium dioxide. For the $\mathrm{HNO}_{3}-\mathrm{HF}$ system, a tenfold increase in the HF concentration increases the weight percent plutonium dioxide dissolved from about $40 \%$ to approximately $100 \%$ for $9 \mathrm{hr}$ of reaction time (Figure 6). A twofold increase in the $\mathrm{HF}$ concentration for the $\mathrm{HNO}_{3}-\mathrm{HF}-\mathrm{H}_{2} \mathrm{SO}_{4}$ system increases the weight percent plutonium dioxide dissolved from $94 \%$ to $100 \%$ for $9 \mathrm{hr}$ of reaction time (Figure 7). As can be seen in Table 1 , any dissolution 


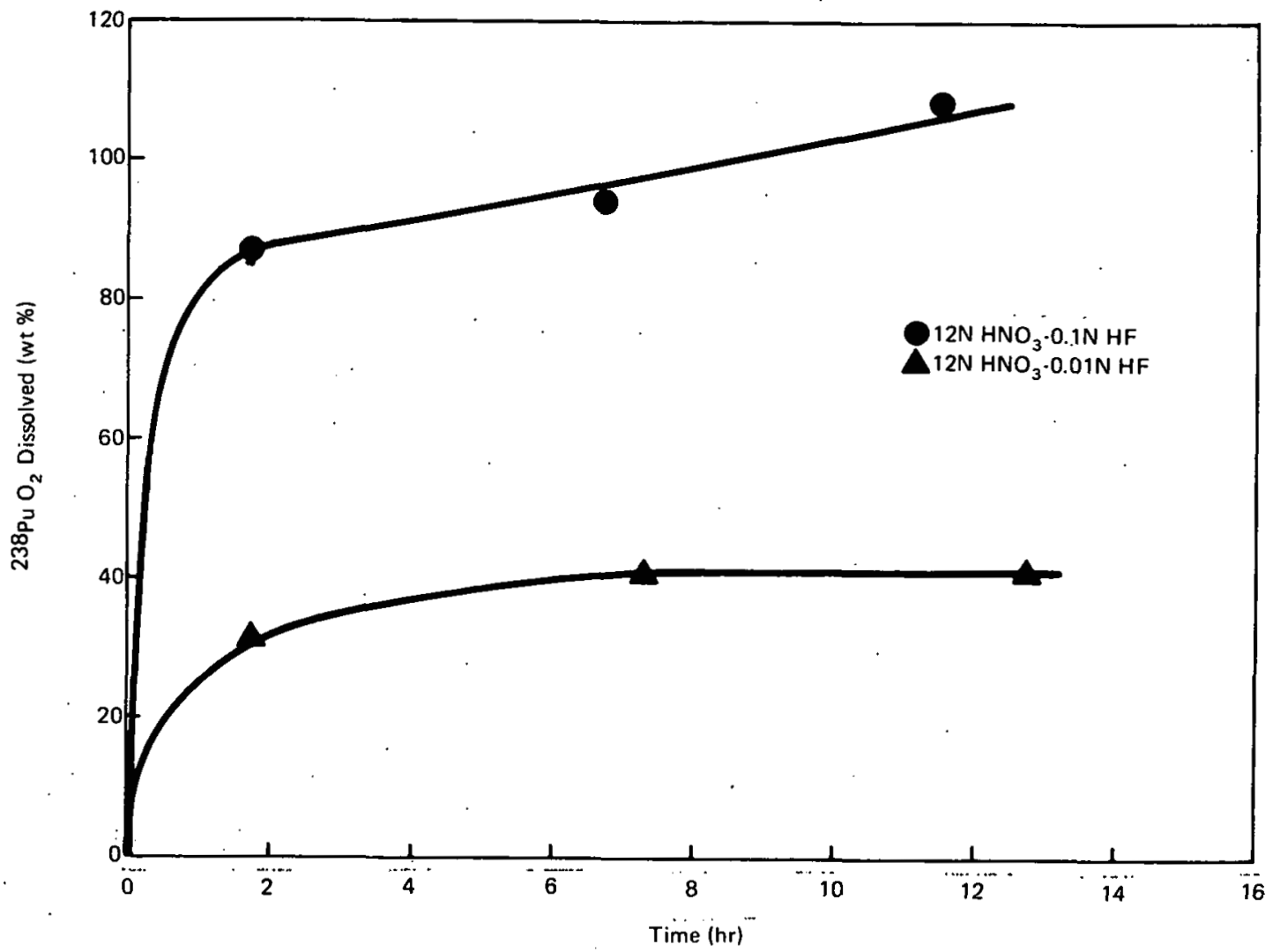

FIGURE 6 - Effect of HF concentration on dissolution rate of $\mathrm{PuO}_{2}$.

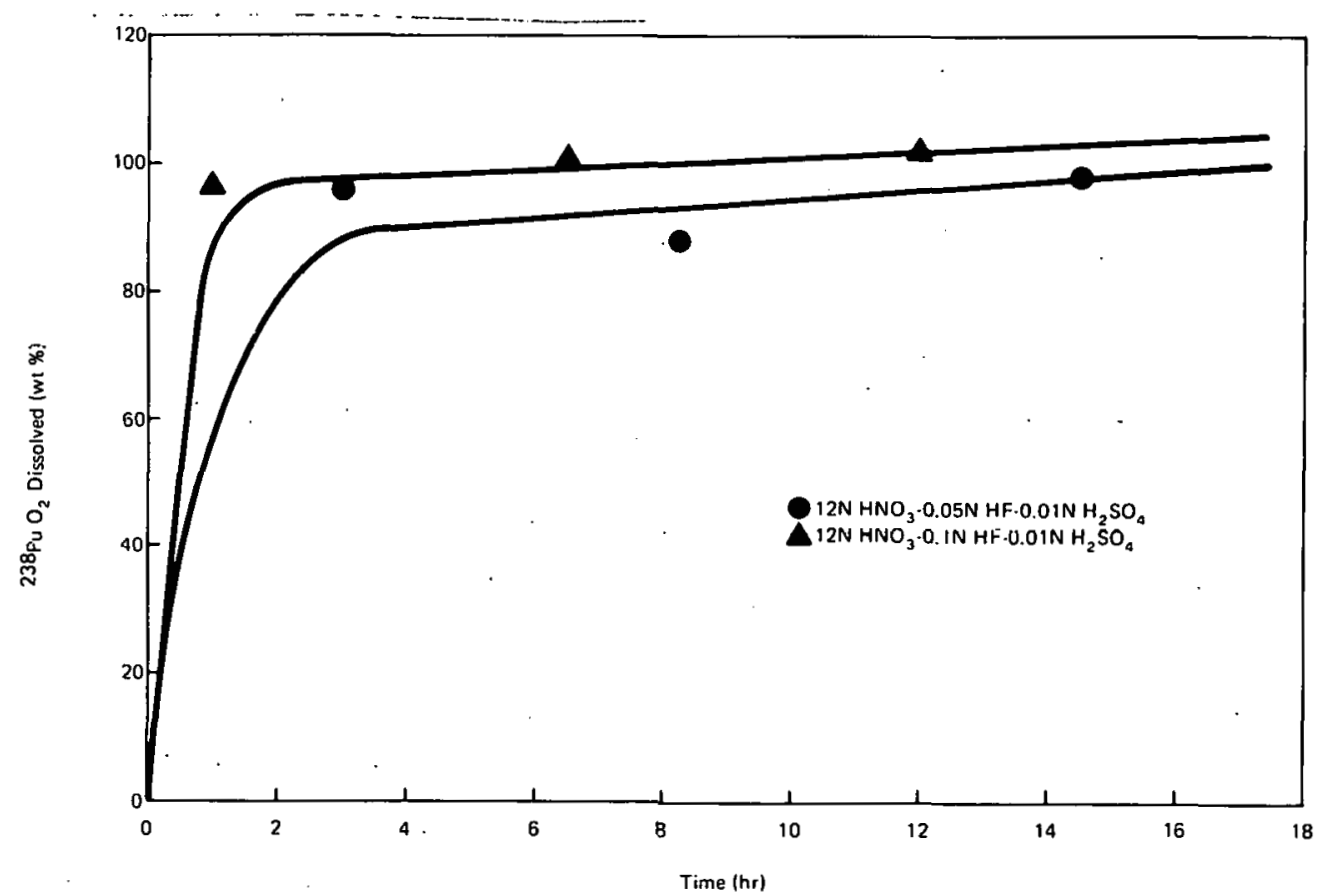

FIGURE 7 - Effects of $\mathrm{HF}$ and $\mathrm{H}_{2} \mathrm{SO}_{4}$ concentrations on dissolution rate. 
test in which HF concentration was $0.05 \mathrm{~N}$, or greater, was successful in obtaining a. 90 to $100 \%$ dissolution of the plutonium dioxide.

\section{$\mathrm{UO}_{\overline{2}}$ and $U_{\overline{3}} \mathrm{O}_{\overline{8}}$ Dissolution Studies}

Contaminated filter media samples were prepared by mixing $0.2 \mathrm{~g}$ of either $\mathrm{UO}_{2}$ or $\mathrm{U}_{3} \mathrm{O}_{8}$ * with $2.8 \mathrm{~g}$ of shredded filter media. These samples were combined in a glass round-bottom flask containing $250 \mathrm{ml}$ of the desired leaching solution. The flasks were attached to reflux condensers, and the contents were heated and refluxed at boiling temperatures. Samples were withdrawn periodically, and the uranium concentration of the solution was determined.

Table 2 lists results of dissolution tests for uranium oxide in various acid mixtures. As can be seen, in every test the uranium oxides dissolved rapidly with the percent dissolved being greater than $90 \%$. Eight normal $\mathrm{HNO}_{3}$ performed as well as any of

*The $\mathrm{U}_{3} \mathrm{O}_{8}$ had been fired at $950^{\circ} \mathrm{C}$ for $2 \mathrm{hr}$. the acid mixtures with essentially 1008 of the uranium dioxide or $\mathrm{U}_{3} \mathrm{O}_{8}$ dissolved after $6 \mathrm{hr}$ of heating. As a comparison, the percent plutonium dioxide dissolved after $6 \mathrm{hr}$ was $\sim 48$ (see Figure 1).

\section{Summary}

Plutonium adsorption isotherms were developed for the $\mathrm{Pu}-\mathrm{HNO}_{3}$ and $\mathrm{Pu}-\mathrm{HNO}_{3}-\mathrm{HF}$ systems which proved that the filter media did indeed adsorb plutonium. The $x / m$

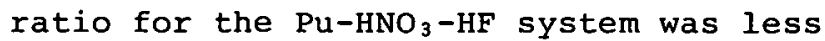
than that for the $\mathrm{Pu}-\mathrm{HNO}_{3}$ system at any given concentration. Thus, higher decontamination factors can be obtained with $\mathrm{HNO}_{3}-\mathrm{HF}$ (assuming each leaching agent is equally effective in the dissolution of plutonium dioxide).

Dissolution tests were conducted on filter media contaminated with plutonium dioxide.**

**The effect of sintering temperature on dissolution rate for various reagents can be seen in Figures 8 and 9 .

\begin{tabular}{|c|c|c|c|}
\hline $\begin{array}{l}\text { Acid Test } \\
\text { Number } \\
\end{array}$ & Reagent Composition & $\begin{array}{c}\text { Time } \\
\text { Heated } \\
\text { (hr) }\end{array}$ & $\begin{array}{c}\mathrm{UO}_{2} \text { or } \mathrm{U}_{3} \mathrm{O}_{8} \\
\mathrm{Dissolved} \\
\text { (wt } \mathrm{w} \text { ) } \\
\end{array}$ \\
\hline $\mathrm{UO}_{2}-1-1$ & $12 \mathrm{~N} \mathrm{HNO}_{3}-0.01 \mathrm{~N} \mathrm{HF}-0.1 \mathrm{~N} \mathrm{H}_{2} \mathrm{SO}_{4}$ & $1 / 2$ & 92.8 \\
\hline $\mathrm{UO}_{2}-1-2$ & $12 \mathrm{NHNO}_{3}-0.01 \mathrm{~N} \mathrm{HF}-0.1 \mathrm{~N} \mathrm{H}_{2} \mathrm{SO}_{4}$ & $61 / 2$ & 94.1 \\
\hline $\mathrm{UO}_{2}-2-1$ & $12 \mathrm{NHNO}_{3}-0.1 \mathrm{~N} \mathrm{HF}-0.01 \mathrm{NH}_{2} \mathrm{SO}_{4}$ & 1 & 91.0 \\
\hline $\mathrm{IO}_{2}-2-2$ & $12 \mathrm{~N} \mathrm{HNO}_{3}-0.1 \mathrm{~N} \mathrm{HF}-0.01 \mathrm{~N} \mathrm{H}_{2} \mathrm{SO}_{4}$ & 7 & 99.6 \\
\hline $\mathrm{UO}_{2}-3-1$ & $12 \mathrm{~N} \mathrm{HNO}_{3}-0.1 \mathrm{~N} \mathrm{H}_{2} \mathrm{SO}_{4}$ & $43 / 4$ & 99.3 \\
\hline $\mathrm{UO}_{2}-4-1$ & $8 \mathrm{~N} \mathrm{HNO}_{3}$ & $53 / 4$ & 102.8 \\
\hline $\mathrm{U}_{3} \mathrm{O}_{8}-5-1$ & $8 \mathrm{~N} \mathrm{HNO}_{3}$ & 1 & 107.0 \\
\hline $\mathrm{U}_{3} \mathrm{O}_{8}-6-1$ & $12 \mathrm{~N} \mathrm{HNO}_{3}-0.1 \mathrm{~N} \mathrm{H}_{2} \mathrm{SO}_{4}$ & 1 & 103.0 \\
\hline
\end{tabular}




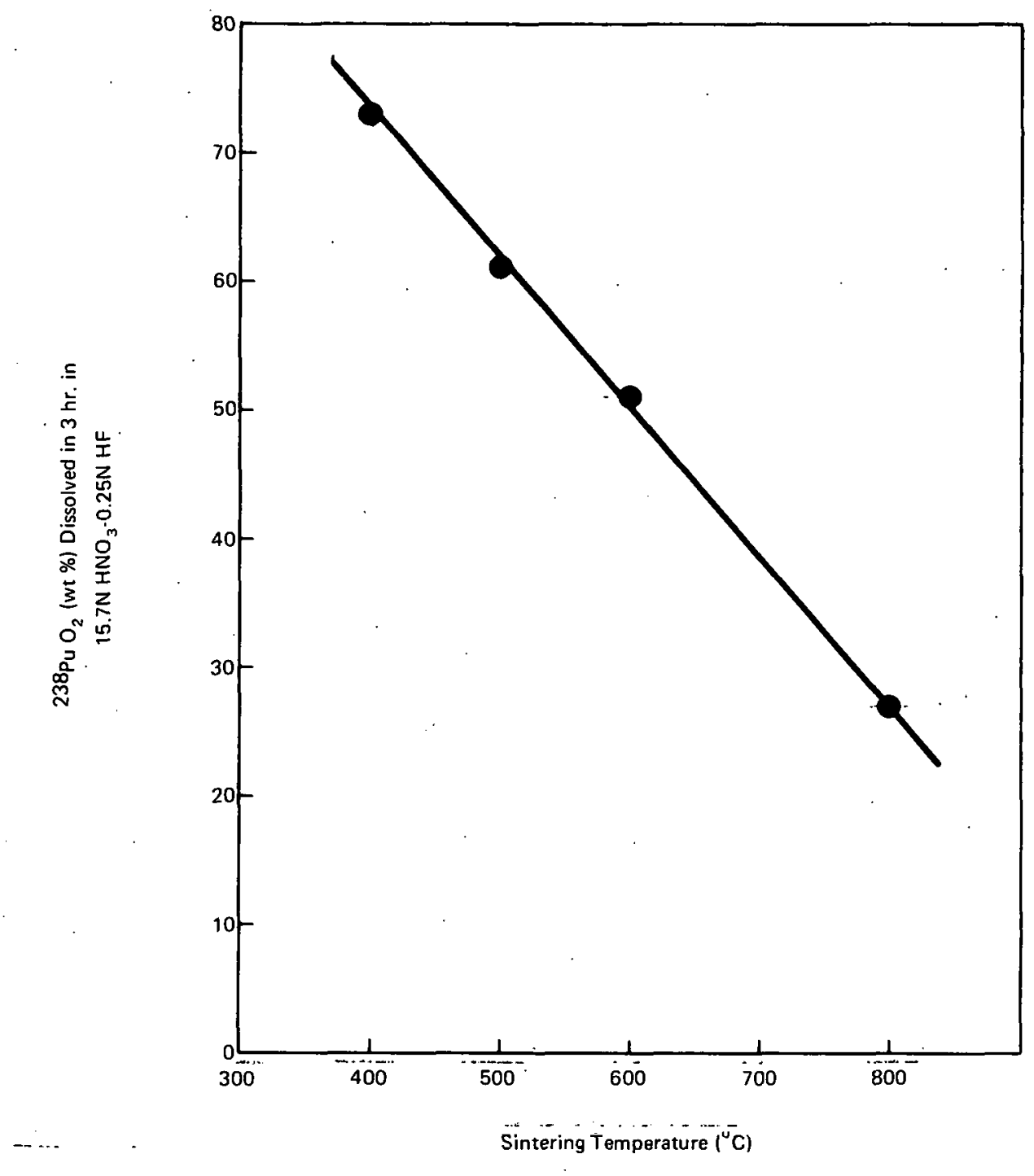

FIGURE 8 - Effect of sintering temperature on dissolution rate.

The $\mathrm{HNO}_{3}-\mathrm{H}_{2} \mathrm{SO}_{4}$ mixtures were relatively ineffective as leaching agents (see Figure 3). The best dissolution agents found were mixtures of $\mathrm{HNO}_{3}-\mathrm{HF}$ and $\mathrm{HNO}_{3}-$ $\mathrm{HF}-\mathrm{H}_{2} \mathrm{SO}_{4}$ in which the $\mathrm{HF}$ concentration was $0.05 \mathrm{~N}$ or greater. These solutions dissolved greater than $90 \%$ of the plutonium dioxide in $15 \mathrm{hr}$ (see Figures 6 and 7). Several tests were performed with $\mathrm{HNO}_{3}-\left(\mathrm{NH}_{4}\right)_{2} \mathrm{Ce}\left(\mathrm{NO}_{3}\right)_{6}$ solutions (see Figures 4 and 5). It was found that $4 \mathrm{~N}$ $\mathrm{HNO}_{3}-0.1 \mathrm{M}\left(\mathrm{NH}_{4}\right)_{2} \mathrm{Ce}\left(\mathrm{NO}_{3}\right)_{6}$ was the best of these mixtures with 88 of of the plutonium dioxide dissolved in $3 \mathrm{hr}$. Also, the percent plutonium dioxide dissolved was found to be directly proportional to the initial cerium(IV) concentration in the leaching solution. Addition of $\mathrm{KMnO}_{4}$ to $4 \underline{\mathrm{N}} \mathrm{HNO}_{3}$-cerium(III) dissolution mixtures was successful in oxidizing the cerium(III) to cerium(IV) and thus allowing more of the plutonium dioxide to dissolve.

Several dissolution tests were completed with uranium dioxide and $\mathrm{U}_{3} \mathrm{O}_{8}$ contaminated filter media. All leaching agents tested dissolved the uranium oxide rapidly (see Table 2). Eight normal $\mathrm{HNO}_{3}$ performed as 


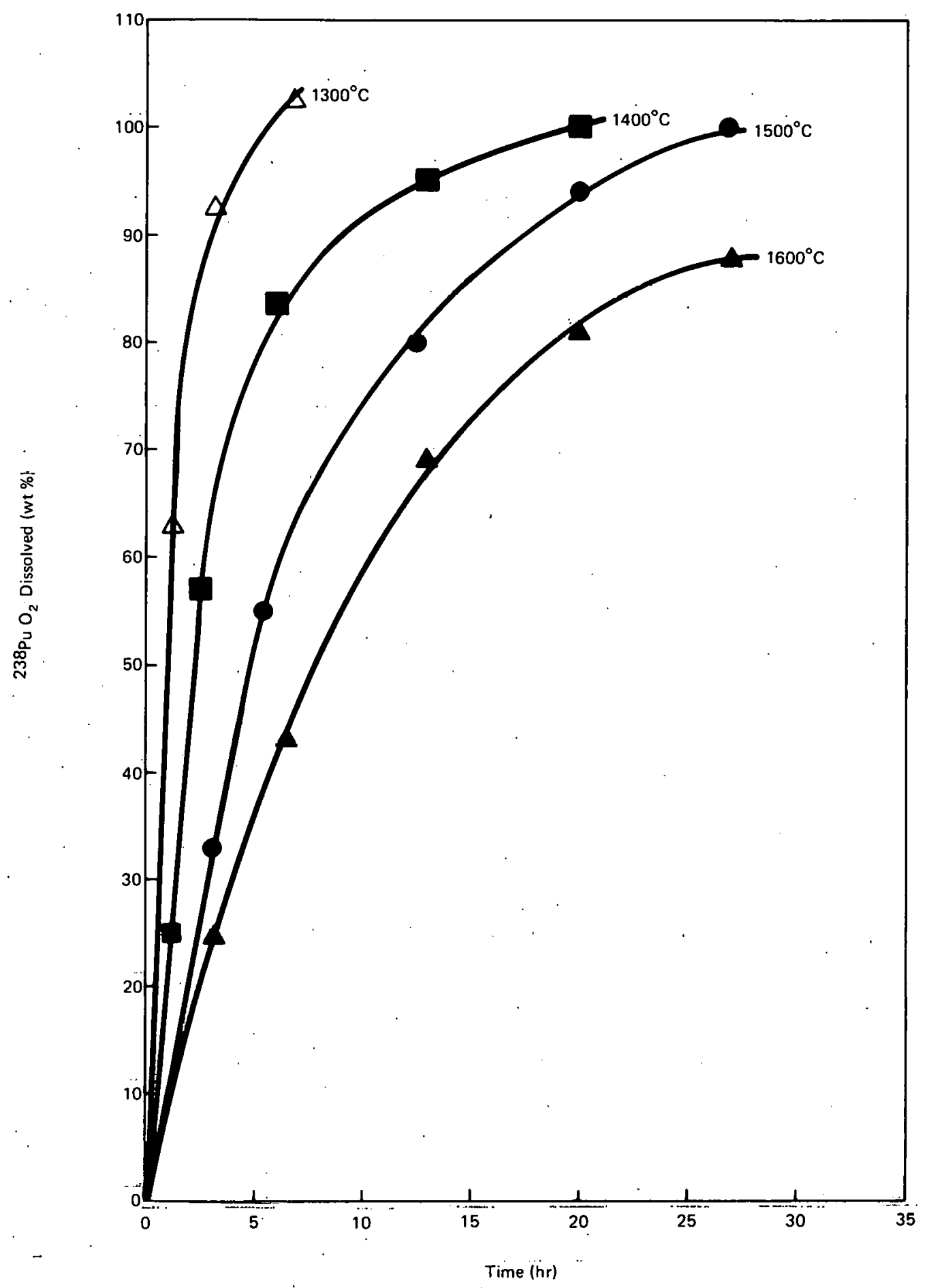

FIGURE 9 - Effect of sintering temperature on plutionium dioxide dissolution in $4 \mathrm{~N}^{\mathrm{HNO}_{3}-}$ $0.15 M$ cerium(IV). 
well as any of the leaching solutions with $\sim 1008$ of the uranium dioxide or $\mathrm{U}_{3} \mathrm{O}_{8}$ dissolved in $6 \mathrm{hr}$.

Figure 10 is a proposed flowsheet showing a four-stage dissolution process, assuming 908 actinide removal in each stage. The dissolution agent used is $12 \mathrm{~N} \mathrm{HNO}_{3}-0.05 \mathrm{~N}$ $\mathrm{HF}-0.01 \mathrm{~N} \mathrm{H}_{2} \mathrm{SO}_{4}$ which proved to be successful in the recent plutonium dioxide studies. Another possible dissolution agent is $4 \underline{\mathrm{N}} \mathrm{HNO}_{3}-0.1 \mathrm{M}\left(\mathrm{NH}_{4}\right)_{2} \mathrm{Ce}\left(\mathrm{NO}_{3}\right)_{6}$, but this would require a five-stage process in order to obtain a decontamination factor of $10^{4}$. On the other hand, if higher concentrations of cerium(IV) were used, a four-stage process is possible.

Next quarter, $\mathrm{Na}_{2} \mathrm{CO}_{3}-\mathrm{KNO}_{3}$ fusion tests will be performed. Tests will be conducted using plutonium dioxide, and if a high percentage of dissolution is achieved, additional tests will be performed using other actinides. Decontamination solutions, such as EDTA, will also be investigated. The work next quarter, however, will be directed primarily toward evaluating $12 \underline{\mathrm{N}} \mathrm{HNO}_{3}-0.05 \underline{\mathrm{N}} \mathrm{HF}-0.01 \underline{\mathrm{N}} \mathrm{H}_{2} \mathrm{SO}_{4}$ and $4 \underline{\mathrm{N}} \mathrm{IINO}_{3}-0.1 \mathrm{M}\left(\mathrm{NH}_{4}\right)_{2} \mathrm{Ce}\left(\mathrm{NO}_{3}\right)_{6}$ reagents for tests on oxides of americium-24l, neptunium237, uranium-233, and curium-244.

The milestone chart status is shown in Figure 11. Milestones $A$ and $B$ have been completed except for fusion tests using plutonium. Part $\mathrm{C}$ will involve determining leach parameters (possibly fusion parameters also) for other actinides as americium-241, uranium-233, curium-244, and neptunium-237. Material balances will be done, flowsheets will be prepared, and decontamination factors will be determined. At this time, indications are that the decontamination process will be a four-stage operation with each stage removing approximately 908 of the actinides (see Figure 10). In Part D, waste streams from the most feasible processes will be studied, and comparisons will be made among them. Materials balances will also be prepared on the waste streams.

\section{References}

1. G. I. Silver and J. W. Koenst, A Study of the Reaction of Uranium and Plutonium with Bone Char, MLM-2384 (January 17, 1977), p. 24 .

2. D. E. Etter and W. R. Herald, Plutonium238 Dioxide Dissolution Study, MLM-2153 (July 31, 1974), 8 pp.

3. H. D. Harmon, Dissolution of $\mathrm{PuO}_{2}$ with $\mathrm{Ce}^{+4}$ and Fluoride Promoters, DP-1371, Savannah River Laboratory (1975), 31 pp.

\section{Bibliography}

C. H. H. Chong, T. W. Crockett and J. W. Doty, Jr., J. Inorg. Nucl. Chem., 31, 81 (1969).

G. L. Silver, Dissolution Processes, MLM2372 (October 1976), $17 \mathrm{pp}$.

R. M. Black and J. L. Drummond, A Comparison of Procedures for Dissolving Ignited Plutonium Oxides for Analysis, TRG Report 1072 (D), Reactor Group, United Kingdom Atomic Energy Authority, Risley, England (Oct. 4, 1965).

D. R. Rogers and W. B. Brown, Potassium Plutonium Sulphate, MLM-1212 (1964), 13 pp.

G. F. Molen, Dissolution of Plutonium Oxide, RFP-922, Dow Chemical-Rocky Flats, (August 29, 1967), 20 pp. 


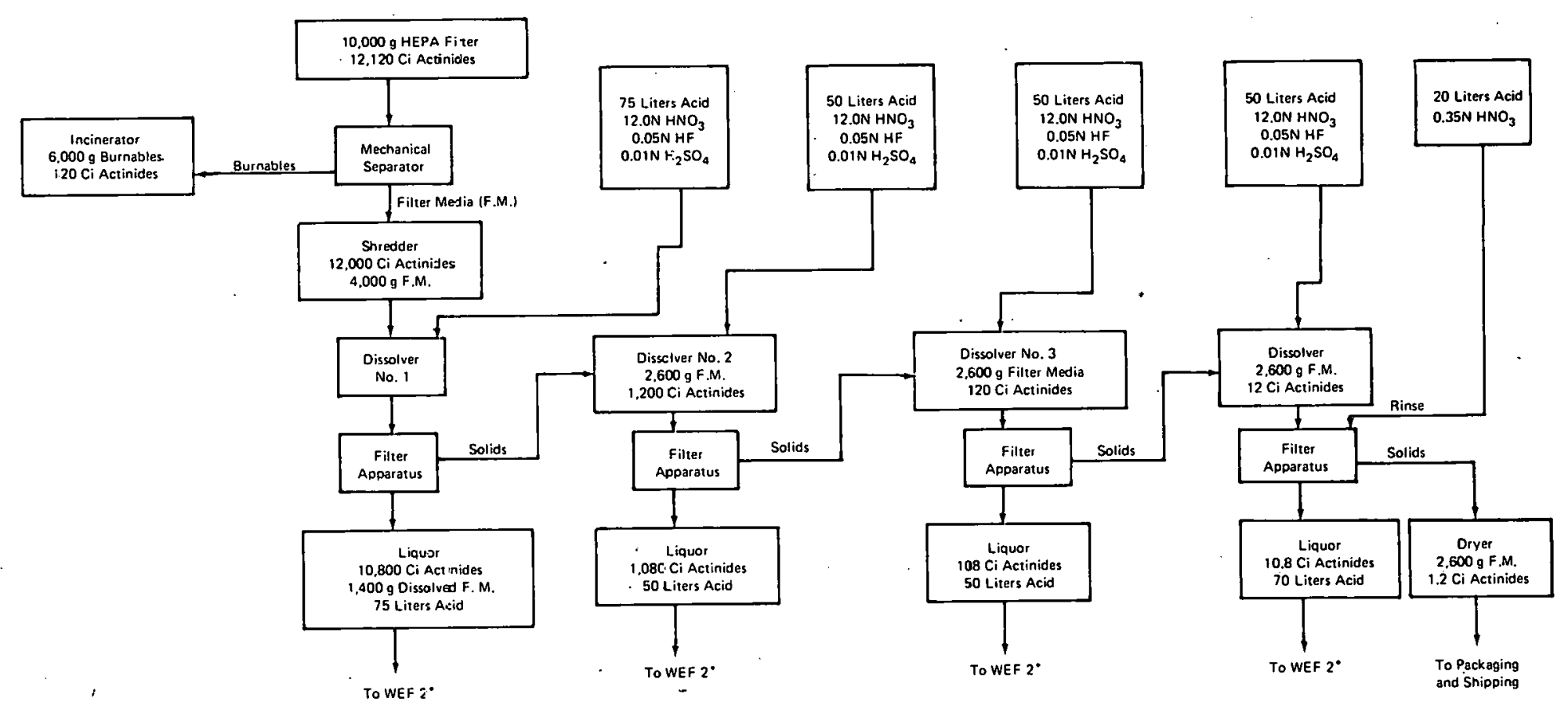

-WEF 2 - NG.norganic contaminated, tititiated water feed sream 
H. W. Crocker, Ammonium Bifluoride Fusion of Ignited $\mathrm{PuO}_{2}$, $\mathrm{HW} 68655$, General Electric Co., Richland, Wash. (February 1961), 5 pp.
Light Water Reactor Fuel Recycle October December 1976, DPST-LWR-76, Savannah River Laboratory, pp. 1-4.

\section{MILESTONES}

PHASE I

A. Determine Parameters of $\mathrm{HNO}_{3}$ Leach Tests with Plutonium

B. Determine Parameters of Alternate Reagent Leach Tests with Plutonium

C. Determine Leach Parameters for Other Actinides

D. Determine and Compare Waste Streams from Sélected Proctesses

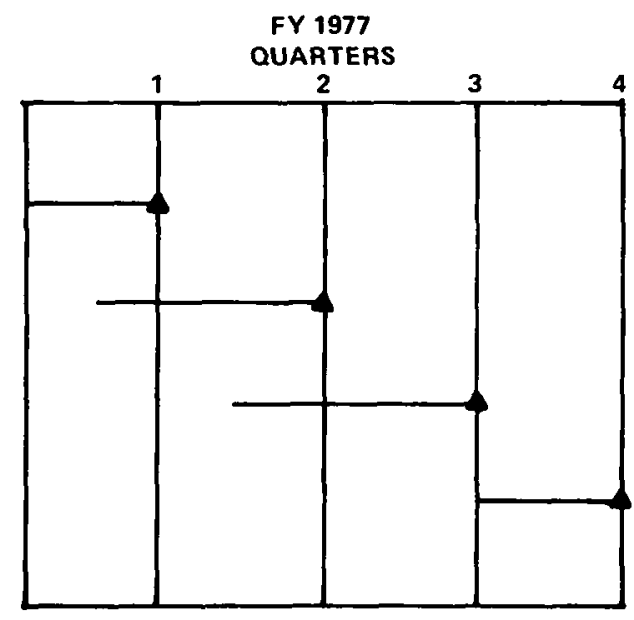

FIGURE 11 - Milestone chart status. 


\section{Distribution}

EXTERNAL

TIC, UC-70 (277)

J. A. Chacon, ERDA/DAO (2)

D. Davis, ERDA/ALO (2)

R. A. Wolfe, ERDA/DWMPR (2)

T. K. Kèenan, LASL

J. O. Blomeke, ORNL

A. K. Williams, AGNS

R. K. Flitcraft, MRC

INTERNAL
A. G. Barnett
W. H. Bond
W. T. Cave
J. W. Doty
K. V. Gilbert
C. w. Huntington
L. V. Jones
J. W. Koenst
B. R. Kokenge
D. F. Luthy
J. R. McClain
D. L. Prosser
R. E. Vallee
H. L. Williams
Library (10)
publirations 